\title{
The roles of cats and dogs in the transmission of Toxoplasma infection in Kuna and Embera children in eastern Panama
}

\author{
Gina D. Etheredge, ${ }^{1}$ Girma Michael, ${ }^{1}$ Michael P. Muehlenbein, ${ }^{2}$ \\ and Jacob K. Frenke/ ${ }^{3}$
}

Suggested citation

Etheredge GD, Michael G, Muehlenbein MP, Frenkel JK. The roles of cats and dogs in the transmission of Toxoplasma infection in Kuna and Embera children in eastern Panama. Rev Panam Salud Publica. 2004;16(3):176-86.

\begin{abstract}
Objective. To examine the relationship between antibody status and various hypothesized risk factors for Toxoplasma gondii infection among two different Amerindian populations in eastern Panama. Following up on earlier research that we conducted, we now explore the role of dogs in the natural transmission of Toxoplasma, the role that dogs play in promoting transmission, the interactive effect of cats and dogs, and the accessibility of infective material to children.

Methods. In 1991, 10 Panamanian medical students conducted interviews and took blood samples from 760 Kuna and Embera children aged 2 through 12 years in the Upper Bayano River Basin and the San Blas Islands. Serologic assays were performed using direct agglutination. The data analyses in the 1990s included univariate, bivariate, and multivariate analyses, without regard to data on dogs. Further bivariate and multivariate analyses were performed in 2003 to examine the contribution of dogs.

Results. In communities with high Toxoplasma antibody prevalence in children, logistic regression suggested that the factors predictive of antibody presence were: compacted soil floors of huts ( $\mathrm{P}=0.001)$, having a dog $(\mathrm{P}=0.038)$, and the interviewer seeing $a$ cat in the house $(\mathrm{P}=0.049)$. Our results suggest that the villagers' dogs play a significant role in facilitating the transmission of Toxoplasma gondii to humans, most often in the presence of cats in the houses, and only in those communities with higher Toxoplasma seroprevalence in children.

Conclusions. Dogs may act as mechanical vectors, by rolling in foul-smelling substances and by ingesting fecal material. In areas of high Toxoplasma prevalence in children and where dogs and cats are plentiful, immunocompromised individuals and pregnant women should be warned of the possibility of acquiring Toxoplasma gondii from dogs as well as from soil contaminated by cats. People should be encouraged to wash their hands after contact with soil, dogs, or cats as well as before eating.
\end{abstract}

Key words Toxoplasmosis, cats, dogs, Indians, Central American, Panama.

1 Tulane University School of Public Health and Tropical Medicine, Department of Epidemiology, New Orleans, Louisiana, United States of America. Send correspondence to: G.D. Etheredge, Department of Epidemiology, SL 18, Tulane University School of Public Health and Tropical Medicine, 1440 Canal Street, Suite 2018, New Orleans, Louisiana 70112, United States of America.
2 Yale University, Department of Anthropology, New Haven, Connecticut, United States of America. (At the time of the study) University of Kansas Medical Center, Department of Pathology and Oncology, Kansas City, Kansas, United States of America; present affiliation: University of New Mexico, Santa Fe, New Mexico, United States of America.
Toxoplasma gondii is an obligate intracellular protozoan with worldwide distribution, with a seroprevalence ranging from $20 \%$ to $75 \%$ in the neotropical areas of the Americas $(1,2)$. (The neotropics is the biogeographic 
region that includes southern Mexico, Central America, South America, and the West Indies.) In Panama, infections with Toxoplasma are very common, and most infections are asymptomatic. The presence of antibodies to Toxoplasma in children is high, especially in areas where cats are numerous, sanitation is poor or absent, and there is high shade and high humidity $(3,4)$. An understanding of the roles of potential risk factors in the transmission of Toxoplasma is of public health importance.

Felines are the definitive hosts of Toxoplasma. During the natural cycle of Toxoplasma gondii, cats become infected by consuming rodents and birds, which are intermediate hosts that contain cysts (bradyzoites) that maintain chronic infection (5). When cats ingest an infected animal, the bradyzoites give rise to enteroepithelial stages, followed by the shedding of oocysts in the cats' feces. Oocysts sporulate in the soil and can lie dormant from weeks to months in moist, shaded locations. Sporozoites within the oocysts are then infectious to humans and other mammals via fecaloral fomite transmission, after which tachyzoites and bradyzoites (multiplying asexual stage) maintain active infection (5).

The important role of oocyst shedding by cats in Toxoplasma transmission has been studied in detail $(6,7)$. It was shown that on islands in the $\mathrm{Pa}$ cific Ocean that the absence of cats was associated with an absence of human antibodies to Toxoplasma, and that the prevalence of antibodies paralleled the population of cats or contact with soil contaminated with cat feces. An excellent discussion of Toxoplasma transmission in Indian populations in sylvatic settings in central Brazil has been presented (8), although at the time of that survey, the role of cats in transmission had yet to be recognized.

In our previous study in Panama in the 1990s (3) we examined the transmission of Toxoplasma in Amerindian (Kuna and Embera) children from communities in nearly natural settings (mostly sylvatic areas with little to no clearing for agriculture) and found a prevalence of antibodies much lower than in children from rural and urban settings in Panama. Our findings in the 1990s were consistent with the theory of transmission by oocysts and the importance of cats in transmission.

Dogs have only recently been considered a factor in the spread of toxoplasmosis $(4,9,10)$. One study (4) indicated that, in comparison to contact with cats, contact with dogs was more highly correlated with increased seroconversion in Panamanian children. That study also suggested that, by eating or rolling in cat feces, dogs might play an important role in the mechanical transmission of Toxoplasma oocysts.

It is clear to nearly any dog owner that dogs and other canids like to roll in odoriferous substances, such as feces (11), though the function of such action is not entirely clear. This behavior may promote the transmission of Toxoplasma from the dog's fur. Canids also have a tendency for coprophagia, or the ingestion of fecal material. In order to investigate if dogs can act as mechanical vectors for Toxoplasma gondii after ingesting cat feces infected with Toxoplasma, mice were inoculated with cells from the infected dogs. That study found that mice could be infected by the infected dogs' cells (9). Though no studies have investigated oocyst reexcretion from ingestion of infected cat feces, it is possible that dogs could excrete some oocysts near human habitats, promoting Toxoplasma transmission to humans (9).

This paper elaborates on the research that we conducted in the 1990s on the role of cats in Toxoplasma infection in Kuna and Embera children (3). It also reexamines the relationship between children's antibody status and various hypothesized risk factors, especially dogs, for Toxoplasma infection in the nearly natural settings of eastern Panama. The communities that we studied in eastern Panama resemble hamlets, and they are different from more developed towns in central and western Panama, which have better roads, larger areas devoted to agriculture, and often follow a gridlike pattern of development. Because it was only recently recognized, we wanted to explore the roles of dogs in the natural transmission of Toxoplasma, along with the interactive effect of cats and dogs and the accessibility of infective material to children. We had not examined the role of dogs in the transmission of Toxoplasma in our earlier research (3) because dogs had yet to be implicated in its transmission. In this new analysis we also explored the possible confounding role of an overarching "community" variable, that is, one that is made up of many attributes of the community, each of which cannot be singled out. This newer analysis, which was done in 2003, did not necessitate further data collection; it is a reexamination of our data, including on dogs, that we collected in 1991.

\section{MATERIALS AND METHODS}

\section{Study location}

We studied children in communities from the Upper Bayano River Basin and the San Blas Islands of Panama in 1991 (3). The study sites in the mainland (Bayano) communities were surrounded by forest, allowing the study of Toxoplasma transmission in a setting that is close to that of a natural rain forest. The Bayano Basin is located east of Panama City, between the Panama Canal and Colombia. The San Blas Islands comprise more than 300 islands located off Panama's Caribbean coast, running from north of Panama City to near Colombia.

\section{Study population}

The study population for the 1990s analyses and for the present analyses are the same. We chose to study children 2-12 years of age for whom travel had been minimal and history of residence could be better defined than at later ages. Because this age group was the most stable one residentially, it was considered to be the one best suited for studying differences in circumstances that may lead to acquiring infection. Mothers would not have as many recall problems with the young 
group as they would with an older population since there would be fewer years to consider.

The two ethnic groups studied, the Kuna and the Embera, live in villages that are relatively ethnically homogeneous (that is, either all-Kuna or allEmbera). The Kuna live in the Northern Bayano Basin and the San Blas Islands. The Embera live in the Bayano Basin and also farther east, towards Colombia. Using the national census, and with the aid of personnel from the Bureau of the Census of Panama, one of the authors (GDE) listed all Kuna villages and Embera villages in the Bayano and in the San Blas Corregimiento de Narganá (the district closest to the Bayano Basin). The villages were grouped by mainland or island and stratified by population size, after which 13 villages were randomly selected for study inclusion: 4 of 15 mainland villages and 9 of 29 island ones. Each island has one and only one community. The name of the island is synonymous with the name of the community. The selected islands were densely populated, with little open space. Permission to work in both the mainland and island Kuna villages was granted after visits with the highest leaders in the Kuna hierarchical structure (3). The Embera did not have the strict hierarchical structure of the Kuna and did not require specific permission granted by the community leaders.

\section{Data collection}

In 1991, 10 specially instructed Panamanian medical students conducted interviews that were based on questions formulated by two of the authors (GDE and JFK). In each Kuna village, interpreters who spoke both Spanish and Kuna were trained to work with the interviewers, who spoke Spanish. The Embera population was bilingual in Embera and Spanish, so no interpreters were needed in their communities.

As described earlier (3), the interview was preceded by an explanation of the study by the data collector, and the mother's signed informed consent was obtained. After the interview, capillary blood samples were collected on filter paper from each study-eligible child (that is, 2-12 years of age), airdried, and stored at ambient temperature until sent to Panama City weekly, where they were frozen at $-20{ }^{\circ} \mathrm{C}$. Serological samples from cats were collected during another visit to the communities by GDE, as described earlier (3). Cats were immobilized in a section of jeans legs, with drawstrings at both ends of that section. Blood was obtained from the marginal vein of the ear. Cat blood samples were also collected on filter paper, and they were treated in the same manner as the children's blood samples, for both sample collection and analysis.

The dye test for Toxoplasma antibody (12) was performed at the Gorgas Memorial Laboratory, Panama City, for both children and cats, as previously described (3). A 7-mm disk was punched from each filter paper blood sample. The sera were eluted for immunoglobulin $G$ antibodies, using the direct Toxoplasma agglutination method. Undiluted sera were screened first. If positive, sera were serially diluted to determine the specific antibody titer. Antigen was provided by Dr. Philippe Thulliez (Institut de Puériculture, Paris, France). We began the dilution testing at 1:40, and specimens positive at this or a greater dilution were considered positive for this study.

Information on dogs was collected in 1991, along with detailed cat information. The information on dogs was collected at that time simply to mitigate any damaging effects to cats. Since the respondents answered questions about both cats and dogs, they would not attribute any negative feelings solely to cats. The dog information, however, was not analyzed at that time, as the role of dogs in the transmission of Toxoplasma was unknown.

\section{Statistical methods}

The data analyses in the 1990s included univariate, bivariate, and multi- variate analyses without regard to data on dogs (3). Further bivariate and multivariate analyses were performed in 2003 to examine the contribution of dogs. The data from the 1991 interviews and the serologic examinations were recorded using the dBASE III software package (Ashton Tate, Torrance, California, United States of America). Two software packages were used for the 2003 bivariate and multivariate analyses: Biomedical Data Processing (BMDP) version 7.0 software (Health Sciences Computing Facility, University of California, Los Angeles, California, United States) and Epi Info (Centers for Disease Control and Prevention, Atlanta, Georgia, United States). For both the 1990s and 2003 analyses, children's antibody status was examined in relation to the hypothesized risk factors using chisquare $\left(\chi^{2}\right)$ tests. To determine the association between potential risk factors and children's positive antibody status, odds ratios (ORs) and 95\% confidence intervals (CIs) were calculated. The explanatory power of each independent variable taken in combination with the other independent variables was determined by stepwise logistic regression. Antibody status was considered the outcome (dependent) variable for purposes of multivariate analyses.

\section{RESULTS}

\section{Population and antibody distributions}

Table 1 shows the total population and the number of children in each of the 13 study communities, according to the 1990 Panamanian national census (13). Complete interview and serologic data were collected for 760 children (44\% male) from the 13 communities, representing $89 \%$ of the eligible children (the participation rates ranged from $82 \%$ to $100 \%$ ). There was a relatively even distribution of ages between 2 and 12 years in all the communities.

There was a considerable range in the prevalence of antibody to Toxoplasma in children in the various com- 
TABLE 1. Distribution of the study population by community, Panama, 1991

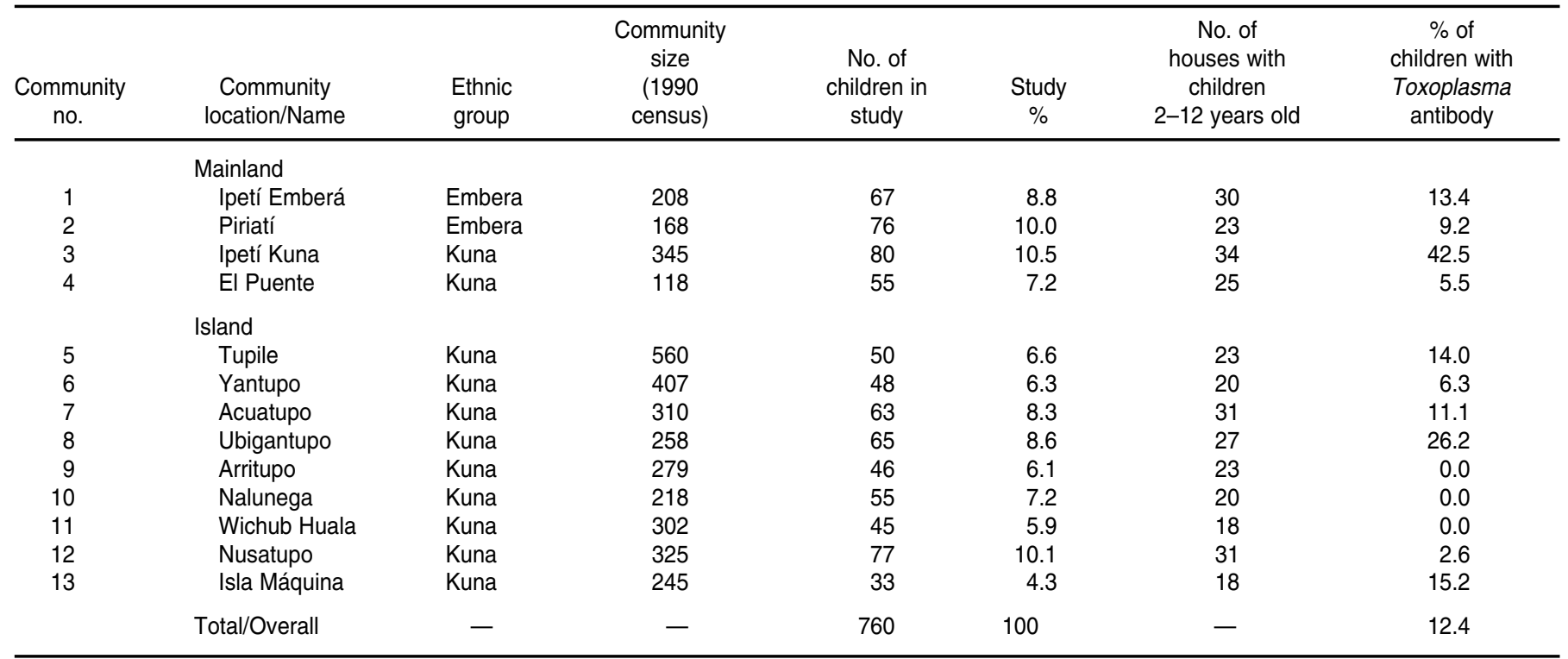

munities (Table 1). There were no significant differences in antibody status between the Embera and the Kuna, nor was there a significant difference in antibody status by sex. However, there was a significant difference in antibody status when mainland children (Embera and Kuna) were compared to island children (Kuna), as well as when Kuna communities on the mainland were compared with Kuna communities on the islands. On the mainland, 53 of the 278 children (19.1\%) were seropositive, as compared with 41 of
$482(8.5 \%)$ on the islands $(P<0.0001)$ (Table 2). Kuna mainland communities also had many more seropositive children $(27.4 \%)$ than did the islands (all Kuna) $(8.5 \%)(P<0.0001)$.

Although the initial survey did not include a complete cat census, an attempt was made to bleed cats in all of the communities, both mainland and island, approximately five months post survey. Of the 14 cats available for bleeding on the mainland, 9 of them $(64 \%)$ were seropositive, as were $12(46 \%)$ of the 26 cats from the islands

TABLE 2. Distribution of human and cat antibody status by locale, Panama, 1991

\begin{tabular}{lccccc}
\hline Group & No. tested & No. positive & \% positive & $\chi^{2}$ & $P$ \\
\hline $\begin{array}{l}\text { Human, Kuna + Embera } \\
\quad \text { Mainland }\end{array}$ & 278 & 53 & 19.1 & 17.17 & $<0.0001$ \\
$\quad$ Island & 482 & 41 & 8.5 & & \\
Human, Kuna only a & & & & 32.42 & $<0.0001$ \\
$\quad$ Mainland & 135 & 37 & 27.4 & & \\
$\quad$ Island & 482 & 41 & 8.5 & & \\
$\quad$ Cat & & & & 1.20 & 0.27 \\
$\quad$ Mainland & 14 & 9 & 64.3 & & \\
$\quad$ Island & 26 & 12 & 46.2 & & \\
\hline
\end{tabular}

a The Kuna population is cited separately because the Kuna live in both mainland communities and island communities, which have very different prevalences of antibody.

(Table 2). The percentage of cats with antibody was greater on the mainland $(64 \%)$ than on the islands $(46 \%)$, though not significantly so $(P=0.27)$.

Overall, there were more dogs per child on the mainland (5.0 dogs per 10 children) than there were on the islands (1.6 dogs per 10 children) (Table 3). A $t$ test for equality of means for dogs on mainland or islands showed a statistically significant difference $(t=$ $3.24, P=0.039)$. Although the number of cats per 10 children was relatively similar for the mainland and island communities (3.7 mainland vs. 3.1 island), the antibody prevalence among children was more than twice as great on the mainland $(19.1 \%$ mainland vs. $8.5 \%$ island). However, this difference was not statistically significant $(t=$ 0.836, $P=0.436)$.

\section{Associations between antibody status and cats and dogs}

To determine whether having a cat in the house ("¿Hay gatos en la casa?") or having a dog (" ¿Tiene perros?") was significantly related to the probability of seropositivity in Kuna or Embera children, crude odds ratios were calcu- 
TABLE 3. Distribution of dogs and cats per number of children in each community, and prevalence of antibodies in children, Panama, 1991

\begin{tabular}{|c|c|c|c|c|c|c|c|}
\hline \multirow[b]{2}{*}{ Location/Village } & \multirow{2}{*}{$\begin{array}{l}\text { No. of } \\
\text { dogs }\end{array}$} & \multirow{2}{*}{$\begin{array}{l}\text { No. of } \\
\text { cats }\end{array}$} & \multirow{2}{*}{$\begin{array}{l}\text { No. of } \\
\text { children }\end{array}$} & \multirow{2}{*}{$\begin{array}{c}\text { Dogs } \\
\text { per } 10 \\
\text { children }\end{array}$} & \multirow{2}{*}{$\begin{array}{c}\text { Cats } \\
\text { per } 10 \\
\text { children }\end{array}$} & \multicolumn{2}{|c|}{$\begin{array}{l}\text { Children } \\
\text { seropositive }\end{array}$} \\
\hline & & & & & & No. & $\%$ \\
\hline \multicolumn{8}{|l|}{ Mainland } \\
\hline Ipetí Emberá & 24 & 22 & 67 & 3.6 & 3.3 & 9 & 13.4 \\
\hline Piriatí & 26 & 23 & 76 & 3.4 & 3.0 & 7 & 9.2 \\
\hline Ipetí Kuna & 45 & 39 & 80 & 5.6 & 4.9 & 34 & 42.5 \\
\hline El Puente & 43 & 20 & 55 & 7.8 & 3.6 & 3 & 5.5 \\
\hline Mainland total/overall & 138 & 104 & 278 & $5.0^{\mathrm{a}}$ & $3.7^{b}$ & 53 & 19.1 \\
\hline \multicolumn{8}{|l|}{ Island } \\
\hline Tupile & 15 & 22 & 50 & 3.0 & 4.4 & 7 & 14.0 \\
\hline Yantupo & 2 & 18 & 48 & 0.4 & 3.8 & 3 & 6.3 \\
\hline Acuatupo & 16 & 14 & 63 & 2.5 & 2.2 & 7 & 11.1 \\
\hline Ubigantupo & 8 & 20 & 65 & 1.2 & 3.1 & 17 & 26.2 \\
\hline Arritupo & 8 & 14 & 46 & 1.7 & 3.0 & 0 & 0.0 \\
\hline Nalunega & 8 & 13 & 55 & 1.5 & 2.4 & 0 & 0.0 \\
\hline Wichub Huala & 6 & 16 & 45 & 1.3 & 3.6 & 0 & 0.0 \\
\hline Nusatupo & 6 & 19 & 77 & 0.8 & 2.5 & 2 & 2.6 \\
\hline Isla Máquina & 8 & 15 & 33 & 2.4 & 4.5 & 5 & 15.2 \\
\hline Island total/overall & 77 & 151 & 482 & $1.6^{\mathrm{a}}$ & $3.1^{b}$ & 41 & 8.5 \\
\hline Mainland + island total & 215 & 255 & 760 & - & - & - & - \\
\hline
\end{tabular}

a For $t$-test for equality of means, number of dogs per 10 children on mainland vs. number of dogs per 10 children on islands, $t=3.24, P=0.039$

${ }^{\mathrm{b}}$ For $t$-test for equality of means, number of cats per 10 children on mainland vs. number of cats per 10 children on islands, $t=0.836, P=0.436$.

lated for having a cat in the house and for having a dog. Table 4 shows that a Kuna or Embera child is twice as likely $(\mathrm{OR}=2.00,95 \% \mathrm{CI}=1.27-3.17)$ to have antibodies to Toxoplasma if there is a cat in the house. However, having a dog alone is only slightly associated with an increase in seroprevalence $(\mathrm{OR}=1.36 ; 95 \% \mathrm{CI}=0.86-2.14)$.

As transmission rates may be related to contact with both a cat and a dog, we assessed the relationship between antibody status in children and having a dog while controlling for having a cat in the house (that is, looking at the association with having $\operatorname{dog}(\mathrm{s})$ and cat(s) in the house, and for having dog(s) but not a cat in the house, separately).

For children who have both cat(s) and $\operatorname{dog}(\mathrm{s})$ in the house (Table 5), the presence of antibodies tends to be associated with the family having $\operatorname{dog}(\mathrm{s})$

TABLE 4. Association that antibody status in children has with cat(s) in the house and with having dog(s), with odds ratio (OR) and 95\% confidence interval (95\% Cl) Panama, 1991

\begin{tabular}{|c|c|c|c|c|c|}
\hline & \multicolumn{2}{|c|}{ Antibody in children } & \multirow[b]{2}{*}{$P$} & \multirow[b]{2}{*}{ OR } & \multirow[b]{2}{*}{$95 \% \mathrm{Cl}$} \\
\hline & Yes & No & & & \\
\hline Cat(s) in the house & & & 0.0015 & 2.00 & $1.27-3.17$ \\
\hline Yes & 45 & 209 & & & \\
\hline No & 49 & 456 & & & \\
\hline Total & 94 & 665 & & & \\
\hline Having dog(s) & & & 0.1648 & 1.36 & $0.86-2.14$ \\
\hline Yes & 48 & 289 & & & \\
\hline No & 46 & 376 & & & \\
\hline Total & 94 & 665 & & & \\
\hline
\end{tabular}

$(\mathrm{OR}=1.70,95 \% \mathrm{CI}=0.83-3.49)$. However, this association does not reach statistical significance, since the $95 \%$ confidence interval includes $1.00(P=$ 0.1190).

For children without a cat in the house (Table 6), having a dog does not increase the likelihood of having antibodies. Thus there appears to be an interactive effect between cats and dogs, given that the odds ratios differ from one another when controlling for having a cat in the house.

We next assessed the relationship of antibody status in children and the number of dogs owned, while controlling for the presence of cat(s) in the house (Tables 7 and 8). For those children with cat(s) in the house and who have $\operatorname{dog}(\mathrm{s})$ (Table 7), an increase in the number of dogs that the family has appears to be associated with an increase in antibody prevalence. However, this association does not reach statistical significance $(P=0.119)$. In the absence of cats (Table 8), an increase in the number of dogs that a family has does not affect antibody prevalence. 
TABLE 5. For families that have cat(s) in the house, the association of antibody status in children and the child's family having dog(s), Panama, 1991

\begin{tabular}{crr}
\hline & \multicolumn{2}{c}{ Having dog(s) } \\
\cline { 2 - 3 } Antibody in children & Yes & No \\
\hline Yes & 29 & 16 \\
No & 108 & 101 \\
Total & 137 & 117
\end{tabular}

a Among those children who have cat(s) in the house, the odds ratio for the child having a positive antibody status and having $\operatorname{dog}(\mathrm{s})$ was 1.70 (95\% confidence interval: $0.83,3.49)(P=0.1190)$

TABLE 6. For families that do not have a cat in the house, the association of antibody status in children and the child's family having dog(s), Panama, 1991 ${ }^{\mathrm{a}}$

\begin{tabular}{crr}
\hline & \multicolumn{2}{c}{ Having dog(s) } \\
\cline { 2 - 3 } Antibody in children & \multicolumn{1}{c}{ Yes } & No \\
\hline Yes & 19 & 30 \\
No & 181 & 275 \\
Total & 200 & 305 \\
\hline
\end{tabular}

${ }^{a}$ Among those children who did not have a cat in the house, the odds ratio for a child having a positive antibody status and having dog(s) was 0.97 (95\% confidence interval: $0.50,1.83)(P=0.9006)$.

TABLE 7. For families that have cat(s) in the house, trends in the association of children's antibody status and the number of dogs that the child's family has, Panama, $1991^{\text {a }}$

\begin{tabular}{|c|c|c|c|c|c|c|}
\hline \multirow{3}{*}{$\begin{array}{l}\text { Antibody } \\
\text { in children }\end{array}$} & \multicolumn{6}{|c|}{ Number of dogs that the child's family has } \\
\hline & \multicolumn{2}{|c|}{ No dogs } & \multicolumn{2}{|c|}{1 or 2 dogs } & \multicolumn{2}{|c|}{$3+$ dogs } \\
\hline & No. of children & $\%$ & No. of children & $\%$ & No. of children & $\%$ \\
\hline Yes & 16 & 13.7 & 24 & 20.7 & 5 & 23.8 \\
\hline No & 101 & 86.3 & 92 & 79.3 & 16 & 76.2 \\
\hline Total & 117 & 100 & 116 & 100 & 21 & 100 \\
\hline
\end{tabular}

a Among those children with cat(s) in the house, the odds ratio (OR) associated with the child having antibody and the child's family having 0 dogs is 1 , the OR of the child having antibody and the child's family having 1 or 2 dogs is 1.65 , and the OR of the child having antibody and the child's family having 3 or more dogs is $1.97 ; \chi^{2}$ for linear trend $=2.45(P=0.119)$.

TABLE 8. For families that do not have a cat in the house, trends in the association of children's antibody status and the number of dogs that the child's family has, Panama, $1991^{\mathrm{a}}$

\begin{tabular}{|c|c|c|c|c|c|c|}
\hline \multirow{3}{*}{$\begin{array}{l}\text { Antibody } \\
\text { in children }\end{array}$} & \multicolumn{6}{|c|}{ Number of dogs that the child's family has } \\
\hline & \multicolumn{2}{|c|}{ No dogs } & \multicolumn{2}{|c|}{1 or 2 dogs } & \multicolumn{2}{|c|}{$3+$ dogs } \\
\hline & No. of children & $\%$ & No. of children & $\%$ & No. of children & $\%$ \\
\hline Yes & 30 & 9.5 & 17 & 9.6 & 2 & 9.1 \\
\hline No & 275 & 90.5 & 160 & 90.4 & 21 & 90.9 \\
\hline Total & 305 & 100 & 177 & 100 & 23 & 100 \\
\hline
\end{tabular}

inside the house $(P<0.01)$ (indicates complete certainty that a cat enters the house); family feeds cat(s) $(P<0.01)$; cats given viscera $(P<0.01)$; and respondent observed cats eating birds $(P<0.01)$. Because meat is usually well cooked and no churrasco (grilled meat on a spit or meat that is barbequed) is eaten by the Kuna or Embera, we excluded transmission to humans by tissue cysts in the study communities. Therefore, the following variables were used in the forward stepwise analysis: child goes to farm, child gardens near the house, cat(s) inside house, family feeds cat(s), respondent observed cats eating birds, compacted soil floor, interviewer sees cat(s) inside house, and drinking piped water. Having a dog also was put in the model selection because in the bivariate analysis it showed a significant interaction with the presence of a cat in the house.

Our first transmission model included all 13 communities in this study, both mainland and island (Table 9). Five variables significantly entered the model: compacted soil floor, cats observed eating birds, drinking piped water, family feeds cat(s), and child gardens near house. Of the 13 communities studied, no antibodies to Toxoplasma were found in children in three island communities (Arritupo, Nalunega, and Wichub Huala) (3). All nine cats that were bled on these three islands were also seronegative (3).

Our second model included only those 10 communities where antibodies were found (Table 9). Six variables significantly entered this model: compacted soil floor, cats observed eating birds, drinking piped water, child gardens near house, cat(s) inside the house, and the family having a dog.

Our third model examined only the mainland communities (Table 9). The four variables that significantly entered this model were compacted soil floor, drinking piped water, cats observed eating birds, and interviewer sees cat(s) inside the house. Having a dog did not enter this model.

Our fourth model examined only the three communities with the highest percentage of children with antibodies to Toxoplasma (Ipetí Kuna, 42.5\%; 
TABLE 9. Multivariate logistic regression analyses using different sets of communities, Panama, 1991

\begin{tabular}{cllr}
\hline Model no. & Communities included & \multicolumn{1}{c}{ Variables entered } & $P$ value \\
\hline 1 & All 13 communities & Compacted soil floor & $<0.001$ \\
& & Cats eat birds & 0.003 \\
& & Drinks piped water & 0.004 \\
& & Family feeds cat(s) & 0.029 \\
2 & Child gardens near house & 0.080 \\
& Antibody-positive communities & Compacted soil floor & $<0.001$ \\
& (10 communities) & Cats eat birds & 0.015 \\
& & Drinks piped water & 0.017 \\
& & Child gardens near house & 0.014 \\
& & Cat(s) in house & 0.037 \\
3 & & Having dog(s) & 0.091 \\
& & Compacted soil floor & $<0.001$ \\
& (4 communities) & Drinks piped water & 0.005 \\
& & Cats eat birds & 0.029 \\
4 & Three communities with highest & Interviewer sees cat(s) in house & 0.063 \\
& antibody prevalence & Compacted soil floor & 0.001 \\
& & Having dog(s) & 0.038 \\
& & Interviewer sees cat(s) in house & 0.049 \\
\hline
\end{tabular}

Ubigantupo, 26.2\%; and Isla Máquina, $15.2 \%$ ) (Table 9). The three variables that significantly entered this model were compacted soil floor, having a $\mathrm{dog}$, and interviewer sees cat(s) inside the house.

Our earlier analyses (3) examined the relationships of antibody presence to various factors, but without considering the contribution of dogs. Those earlier analyses showed that community of residence was the main and only predictor of antibody status. Because of this, we added "community" to the models presented in this article (Table 10). When community was added to the model, community and cat(s) in the house entered for models 1,2 , and 3 . In model 4 (the three communities with the highest antibody prevalence), compacted soil floor, having a dog, and interviewer sees cat(s) in the house entered the model.

\section{DISCUSSION}

In Panama, Toxoplasma transmission by the consumption of tissue cysts can be excluded because meat is generally cooked well (3). The consumption of raw or undercooked meat does not ap-

TABLE 10. Multivariate logistic regression analyses using different sets of communities and including "community" as an independent variable, Panama, 1991

\begin{tabular}{cllr}
\hline Model no. & \multicolumn{1}{c}{ Communities included } & \multicolumn{1}{c}{ Variables entered } & $P$ value \\
\hline \multirow{2}{*}{1} & All 13 communities & Community & $<0.001$ \\
& & Cat(s) in house & 0.029 \\
2 & Antibody-positive communities & Community & $<0.001$ \\
& (10 communities) & Cat(s) in house & 0.029 \\
3 & Mainland communities & Community & $<0.001$ \\
& (4 communities) & Cat(s) in house & 0.035 \\
4 & Three communities with highest & Compacted soil floor & 0.001 \\
& antibody prevalence & Having a dog & 0.038 \\
& & Interviewer sees cat(s) in house & 0.049 \\
\hline
\end{tabular}

pear to play a role in transmission in Panama City either (4). Toxoplasmosis in Latin America is primarily due to contact with soil and possibly also due to contact with water that has been contaminated with oocysts shed by recently infected cats.

The role of oocyst shedding by cats in the Toxoplasma natural transmission cycle is well established, though the exact manner by which cats play a role in transmitting this protozoan to humans in natural, almost-sylvatic settings is still undefined. Domestic cats (Felis catus) in the Kuna and Embera communities were seldom found inside the houses. They tended to be semiferal, spending much of their time during the day in the forest, in woodpiles, or sleeping in the shade of boats, and being active at night (3). In addition, the potential importance of wild cats present in Panama, including Felis concolor (cougar), F. onca (jaguar), F. pardalis (ocelot), F. wiedii (margay), and $F$. yagouaroundi (jaguarundi), must be considered here (14). They have also been shown to be capable of shedding oocysts (15-18).

In our earlier research (3), we examined the transmission of Toxoplasma and demonstrated that childhood seroprevalence was spotty, with no apparent correlation with age, suggesting intermittent transmission. Only two hypothesized risk factors were significantly associated with the presence of antibodies in some communities: floor type of house and having cat(s) in the house. The mainland settlements had higher prevalences than did the island villages, though these mainland prevalences were still lower than those found in Panama City (3). However, the crude estimates of association between postulated risk factors and antibody presence were confounded by strong community attributes. Few statistically significant associations between behavioral risk factors and antibody status were found after controlling for the community of residence.

Reflecting the contribution that wild cats make in transmission, particularly in waterborne transmission $(19,20)$, community of residence might have 
been correlated with the presence of wild cats, although we did not systematically measure this wild cat variable at any time. Oocysts could survive in water for a long time, and waterborne epidemics have been traced to or suspected of being caused by contamination with Toxoplasma oocysts $(19,21)$. Only one of the three study communities with a piped water supply, Ipetí Kuna, had high antibody prevalence. Evidence of the presence of wild cats (paw prints, fecal matter) was investigated at the two upstream water source intake sites for three of the mainland communities (Ipetí Emberá, Piriatí, and Ipetí Kuna) but none was found (3). While other researchers have postulated that rain might wash oocysts into wells (21), no local wells existed in 1991, at the time of our data collection. Domestic cats often roam from the house where they are fed, and the potential for depositing infected feces in the forest near houses of people who do not feed cats is great. Therefore, soil contamination around the homes of cat owners in these communities studied is much lower than it is in a town. In a town, except at its periphery, oocysts are deposited in areas where children play. In our mainland study sites, cats may defecate away from children's play areas, as open areas or forests are nearby. In Costa Rica, researchers were able to ascertain the roaming range of cats and their density in rural areas $(22,23)$. Although this type of information would have been useful for our analyses, we were unable to undertake the formidable task of obtaining such data. The differences that we found in antibody prevalence by community may have less to do with human habits and density of cats than with age structure and oocyst shedding potential of the cat population, oocyst survivability, the number of intermediate hosts, and having a dog that could act as an important transport host. Our current analyses appear to indicate that where there is a high prevalence of antibodies in children and cats, dogs may play a role in transmission (Tables 5-10).

In this study, higher prevalences of Toxoplasma antibodies in children were found in the mainland communities than in the island settlements. This difference was also mirrored in the cat populations; mainland cats had, in general, higher prevalences of Toxoplasma antibodies than did island cats (Table 2). The mainland communities had higher seroprevalences in children as well as higher ratios of dogs and cats to children (Table 3). This makes intuitive sense, with the presence of cats being significantly associated with increased seroprevalence (6). At the same time, island communities had a high density of houses and thus less physical space for cats to defecate. This may produce a higher environmental cat feces concentration, which in turn could contribute to higher community seroprevalences. Proof of this would require accurate measurement of cat population densities and population turnover, which would be a difficult feat when working with elusive seminocturnal animals. Nonimmune kittens are the main oocyst shedders, whereas immunity diminishes or prevents reshedding after reinfection. Most of the cats in the communities studied tended to be in the forest or to hide during the day and then roam the villages at night, hence the difficulty in catching and bleeding many cats during the study period. We were unable in 1991 to evaluate either the prevalence of wild cats (which may play a role on the mainland) or the great variety and number of infected birds and rodents in or near mainland communities. Wild animals are more prevalent on the mainland than on the densely populated islands, where houses were generally separated by only one to two meters (3).

We did not collect infective materials (feces and soil) in the 13 communities of this study. Even if we had collected such samples, it is unlikely that they would have been informative if they had not been intensively collected over a lengthy period of time (3). Oocysts are shed for one to three weeks (24). A cat that has already shed oocysts (post primary infection) will generally not shed again during secondary infection $(25,26)$. A population of actively reproducing cats, with many young, nonimmune kittens will produce more oocysts than will a more stable population of older cats (3). This difference in cat populations, along with differences in the number and composition of the intermediary host population (birds, rodents), may help to explain the variability in seroprevalences among communities.

Another possible factor in the variability in community seroprevalences may be the presence of dogs. Transmission of oocysts from soil can be enhanced by transmission from the fur of contaminated dogs when children pet them or wrestle with them. In Panama City the presence of dogs was highly correlated with that of cats (4). Additionally, contact with nursing and weaned dogs, unsanitary conditions (flies, garbage, cockroaches), and cats were significantly associated with human seroconversion. Dogs remove some infectivity because some oocysts will excyst, and sporocysts will enter the tissues. However, it has been suggested that dogs might contribute to Toxoplasma transmission in two ways: fur contamination and oocyst reshedding near houses following coprophagia of infected cat feces (9). In the laboratory, dogs have been shown to eliminate viable oocysts after ingesting sporulated oocysts in cat feces (10). Effectively, coprophagous dogs represent a net decrease of oocysts in the soil by consuming infected cat feces, thus decreasing the chance of transmission to children. This is consistent with a study (4) that found a relatively low level of soil contamination in Panama City, suggesting sporadic transmission. The low level of soil contamination was hypothesized to be due to cats' habits of defecating in many places, thus distributing their feces. However, dogs would at the same time represent an increased risk for infection because of the potential contamination of their fur and muzzle.

Dogs tend to roll in cats feces; the term "xenosmophilia," or a fondness for foreign smells, has been suggested to describe this practice (9). Infective oocysts could contaminate a dog's fur after the dog rolled in infected cat 
feces, a common practice for both feral and domiciled canines alike (11). Given sufficiently high humidity and shading from direct sun, oocysts on a dog's fur from infected cat feces could possibly survive and infect children (10). Since dogs tolerate petting by children much more than cats do, this could increase the importance of dogs as an indirect vehicle for transmission (9). In contrast, cat fur is generally not contaminated with oocysts.

Our study found that mainland communities had higher seroprevalences in both humans and cats than did island communities. Mainland communities also had more dogs than did the islands (Table 3). However, only "cat(s) in the house" was significantly associated with an increased probability of seroprevalence (Table 4), which is consistent with past reports. When respondents did not report cats coming into the house, having a dog was not significantly associated with seroprevalence. We found that an increase in the number of dogs that a family had, in the absence of cats, slightly decreased children's antibody prevalence (Table 8). This association is compatible with the idea of dogs removing infective material. However, having dogs but no cats in the house did not significantly affect children's antibody prevalence. In households that have dogs but not cats, the dogs may be preventing cats from defecating near the house or in the yard or garden. On the other hand, children from houses that have both cats and dogs demonstrate an increased risk of infection, according to the increase in the number of dogs they have (Table 7). It may be that dogs that are accommodated to the presence of cats, as would be the case in a multiple-animal household, allow the felines to defecate in or around the house or garden. In this case, through fur contamination, the dog might then be playing a role in the transmission of toxoplasmosis. Coprophagic dogs would decrease oocysts from the soil and decrease the chance for children to become infected, although some oocysts could remain on the muzzle of the dog. In contrast, strictly xenosmophilic dogs would promote transmission by fur contamination. It may be more likely that children would become infected by petting or wrestling with dogs than from picking up oocysts from the soil.

Using four different population sets for regression analyses allowed us to maximize our ability to detect "having dogs" as a predictor of antibody status. We used four sets from the total database: all 13 communities, the 10 communities where antibody was detected, the 3 communities with the highest prevalences, and the 4 mainland communities. In all four analyses, compacted soil floor in the house was the most significant predictor of seroprevalence, just as it was the most significant in the bivariate analyses.

A compacted soil floor in the house was three to four times as frequently associated with Toxoplasma seropositivity as was a wooden floor or a floor composed of loose soil; a combination of floors was associated two to three times as frequently. This may be explained by the fact that a cat fecal deposit on compacted soil might be relatively invisible because of the similar color of the feces and the soil floor, and thus more available to contaminate children playing there. In contrast, on loose soil, cats would cover a fecal deposit, and on a wooden floor the feces would likely be noticed and removed. In the study done in Panama City (4), the floor type was mainly concrete, and the seropositivity associated with concrete floors was half that associated with wooden floors; the latter may be associated with lesser affluence and hygiene. In a study in Costa Rica (23), however, a soil floor was associated with the lowest antibody prevalence, and a concrete floor with the highest prevalence.

The "cats eat birds" variable was reported from $40.3 \%$ of the interviews, and it entered into models 1, 2, and 3 (Tables 9 and 10). "Cats eating mice or rats" was infrequently mentioned, and this may be because rodents are nocturnal and less easily observed. Although we did not measure the presence of antibody in either of these animal groups (that is, birds or mice or rats), Toxoplasma was isolated more commonly from birds than from mice in studies in Panama City (3) and in Costa Rican (22).

The "piped water" variable entered into the first, second, and third models. This suggests that this water was more highly contaminated with oocysts than were the two other sources of drinking water, river water and roof water. The highest prevalence of antibodies was found in the community of Ipetí Kuna, where piped water was the main water source, and this may be affecting the contribution of "piped water." Waterborne outbreaks of Toxoplasma infection have been described from Brazil (21), the Canadian province of British Columbia (20), and Panama (19).

The "child gardens near house" variable was reported by parents for $50 \%$ of the children, and it entered into the first model and the second model (Table 9). This is an activity where a child may be contaminated with oocysts from soil contaminated with cat feces. After two or three weeks, however, that soil contamination is unrecognizable as such (27).

The presence of dogs was not significant when looking at all 13 communities (model 1) or when looking at just the mainland communities (model 3) (Table 9). However, when we examine, as a group, just the 10 communities where antibody was detected in children (model 2) and the 3 communities with the highest antibody prevalence (model 4), we see that having a $\operatorname{dog}$ is a significant predictor of seropositivity in children (Table 9).

"Community of residence," when added as an independent variable to the logistic regression analyses for the first three models (Table 10), masked the contribution of all of these variables shown in Table 9: compacted soil floor, cats eat birds, drinks piped water, family feeds cat(s), child gardens near house, having $\operatorname{dog}(\mathrm{s})$, and interviewer sees cat(s) in house. Only when adding "community of residence" as an independent variable was a cat variable ("cat(s) in house" or "interviewer sees cat(s) in house") then included in all four models. Once "community" was added to the fourth model (the three communities where there was the 
highest antibody prevalence), "compacted soil floor" (which was present in each model not considering community (Table 9)), "having dog(s)," and "interviewer sees cat(s) in house" significantly contributed to predicting children's antibody status. In this fourth model, "compacted soil floor" and "having a dog" appear to be more important than "community" in predicting antibody status; "community" was replaced by those two variables. We suspect that "community" was acting as a residual confounder (28).

If dogs are one of the modes of transmission of Toxoplasma, we would expect to see the presence of dogs as an important predictor where antibody prevalence was higher. In the fourth model, which examines only the three communities with the highest prevalences, both when community is included (Table 10) and when it is not (Table 9), we see that having a $\operatorname{dog}$ is a significant predictor of antibodies in children. It may be that dogs play a significant role in facilitating the transmission of Toxoplasma gondii to humans most often in the presence of cats regularly visiting a house to be fed or to raid garbage, and only in those areas of higher human seroprevalence. This pattern would be applicable to areas or periods when cat density is high, and it would be more efficient in the presence of high humidity, which prevents early desiccation of oocysts.

\section{CONCLUSIONS}

Peridomiciliary animals can transmit many infections to humans. An understanding of the general and local incidence, distribution, and pathophysiology of toxoplasmosis is of public health importance. Toxoplasmosis infection is asymptomatic in normal children and in most adults. However, there are increasing numbers of immunocompromised individuals who are at risk. Some of them suffer relapse of chronic infection, and others sustain more severe primary infections (29). The evidence that we have presented suggests that immunocompromised individuals and pregnant women should be warned of the possibility of acquiring Toxoplasma gondii from dogs as well as from soil contaminated by cats. The easiest and most acceptable prevention method to recommend to these populations is hand-washing, both after dog, soil, or cat contact and before eating. This is especially important in the neotropics, where cats and dogs are numerous and humidity tends to be high in the lowlands. Central American Indians generally cook meat well, thus killing any bradyzoites in it. However, Toxoplasma could be acquired through meat consumption in communities that consume churrasco, which may contain undercooked areas near the bone, or kibbe (raw or cooked ground lamb and bulgur wheat), which is often eaten raw. Only meat cooked until its color has changed can be considered safe. These simple acts of hand-washing and thoroughly cooking meat might reduce the transmission of Toxoplasma gondii, and they will also reduce the incidence of the common bacterial or viral infections transmitted from animals to humans (30).

Acknowledgements. The authors thank Ms. Leslie Schwartzmann for her aid in document preparation and Roger Sherwin for his aid in reviewing the paper. This research was supported in part by a Fulbright Fellowship to Gina D. Etheredge.

\section{REFERENCES}

1. Lamb GA, Feldman HA. A nationwide serum survey of Brazilian military recruits. Am J Epi. 1968;87(2):323-8.

2. Feldman HA. Epidemiology of Toxoplasma infections. Epidemiol Rev. 1982;4:204-13.

3. Etheredge GD, Frenkel JK. Human Toxoplasma infection in Kuna and Embera children in the Bayano and San Blas, Eastern Panama. Am J Trop Med Hyg. 1995;53(5):448-57.

4. Frenkel JK, Hassanein KM, Hassanein RS, Brown E, Thulliez P, Quintero-Nunez R. Transmission of Toxoplasma gondii in Panama City, Panama: a five-year prospective cohort study of children, cats, rodents, birds, and soil. Am J Trop Med Hyg. 1995;53(5): $458-68$.

5. Frenkel JK. Transmission of toxoplasmosis and the role of immunity in limiting transmission and illness. J Am Vet Med Assoc. 1990; 196(2):233-40.

6. Wallace GD. The role of the cat in the natural history of Toxoplasma gondii. Am J Trop Med Hyg. 1973;22(3):313-22.

7. Wallace GD, Zigas V, Gajdusek DC. Toxoplasmosis in cats in New Guinea. Am J Trop Med Hyg. 1974;23(1):8-14.
8. Baruzzi RG. Contribution to the study of the toxoplasmosis epidemiology; serologic survey among the Indians of the Upper Xingu River, Central Brazil. Rev Inst Med Trop São Paulo. 1970;12(2):93-104.

9. Frenkel JK, Parker BB. An apparent role of dogs in the transmission of Toxoplasma gondii: the probable importance of xenosmophilia. Ann NY Acad Sci. 1996;791:402-7.

10. Lindsay DS, Dubey JP, Butler JM, Blagburn BL. Mechanical transmission of Toxoplasma gondii oocysts by dogs. Vet Parasitol. 1997: 73(1-2):27-33.

11. Grier JW. Biology of animal behavior. New York: Times Mirror/Mosby; 1984.

12. Wallace GD. Sabin-Feldman dye test for toxoplasmosis. Am J Trop Med Hyg. 1969;18(3): 395-8.

13. Panamá, Contraloría General de la República. Censos nacionales de población y vivienda, 13 de mayo de 1990, 1991. Resultados finales básicos. Panamá: Contraloría General de la República; 1991.

14. Méndez E. Los principales mamíferos silvestres de Panamá. Ciudad de Panamá: Laboratorio Conmemorativo Gorgas; 1970.
15. Jewell ML, Frenkel JK, Johnson KM, Reed V, Ruiz A. Development of Toxoplasma oocysts in neotropical felidae. Amer J Trop Med Hyg. 1972;21(5):512-7.

16. Lukesova D, Literak T. Shedding of Toxoplasma gondii by Felidae in zoos in the Czech Republic. Vet Parasitol. 1998;74(1):1-7.

17. Miller NL, Frenkel JK, Dubey JP. Oral infections with Toxoplasma cysts and oocysts in felines, other mammals, and in birds. J Parasitol. 1972;58(5):928-37.

18. Patton S, Rabinowitz A, Randolph S, Johnson SS. A coprological survey of parasites of wild neotropical felidae. J Parasitol. 1986;72(4): 517-20.

19. Beneson MW, Takafuji ET, Lemon SM, Greenup RL, Sulzer AJ. Oocyst-transmitted toxoplasmosis associated with ingestion of contaminated water. N Eng J Med. 1982; 307(11):666-9.

20. Bowie WR, King AS, Werker DH, Isaac-Renton JL, Bell A, Eng SB, et al. Outbreak of toxoplasmosis associated with municipal drinking water. Lancet. 1997;350(9072):173-7.

21. Bahia-Oliveira LM, Jones JL, Acevedo-Silva J, Alves CC, Oréfice F, Addiss DG. Highly en- 
demic, waterborne toxoplasmosis in North Rio de Janeiro State, Brazil. Emerg Infect Dis. 2003;9(1):55-62.

22. Ruiz A, Frenkel JK. Toxoplasma gondii in Costa Rican cats. Am J Trop Med Hyg. 1980;29(6): 1150-60.

23. Frenkel JK, Ruiz A. Endemicity of toxoplasmosis in Costa Rica. Am J Epi. 1981;113(3): 254-69.

24. Dubey JP, Frenkel JK. Cyst-induced toxoplasmosis in cats. J Protozool. 1972;19(1):155-77.

25. Dubey JP, Frenkel JK. Immunity to feline toxoplasmosis: modification by administra- tion of corticosteroids. Vet Path. 1974;11(4): 350-79.

26. Frenkel JK, Smith DD. Immunization of cats against shedding of Toxoplasma oocysts. J Parasitol. 1982;68(5):744-8.

27. Frenkel, JK, Ruiz A, Chinchilla M. Soil survival of Toxoplasma oocysts in Kansas and Costa Rica. Amer J Trop Med Hyg. 1975;24(3): 439-43.

28. Rothman KJ, Greenland S. Modern epidemiology. Philadelphia: Lippincott-Raven; 1998.

29. Bertoli F, Espino M, Arosemena JR, Fishback $\mathrm{JL}$, Frenkel JK. A spectrum in the pathology of toxoplasmosis in patients with acquired immunodeficiency syndrome. Arch Pathol Lab Med. 1995;119(3):214-24.

30. Acha PN, Szyfres B. Zoonoses and communicable diseases of man and animals. 3rd ed. Washington, D.C: Pan American Health Organization; 2001

Manuscript received 17 March 2003. Revised version accepted for publication on 16 June 2004

RESUMEN Objetivo. Examinar la relación entre la presencia o ausencia de anticuerpos y los diversos factores de riesgo hipotéticos asociados con la infección por Toxoplasma gondii en dos poblaciones amerindias diferentes del este de Panamá. Como secuela a una investigación preliminar, en este trabajo se explora el papel de los perros en la transmisión natural de Toxoplasma y en la facilitación de la transmisión, así como el efecto interactivo de los perros y gatos y el acceso de los niños a materiales infecciosos.

Métodos. En 1991, 10 estudiantes de medicina panameños llevaron a cabo entrevistas y les tomaron muestras de sangre a 760 niños kunas y emberas de 2 a 12 años de edad en la cuenca superior del río Bayano y en las islas de San Blas. Se hicieron pruebas serológicas mediante aglutinación directa. Todos los datos, menos los de los perros, se estudiaron mediante análisis unifactorial, bifactorial y multifactorial. En 2003 se efectuaron nuevos análisis bifactoriales y multifactoriales para examinar la contribución de los perros.

Resultados. En comunidades con una alta prevalencia de anticuerpos contra Toxoplasma en niños, la regresión logística indicó que los siguientes factores tenían valor pronóstico en relación con la presencia de anticuerpos: pisos de tierra compacta en las chozas $(P=0,001)$, tener perro $(P=0,038)$, y que el investigador hubiera visto un gato dentro de la vivienda $(P=0,049)$. Según nuestros resultados, los perros de los habitantes de las aldeas desempeñan un papel importante en la facilitación de la transmisión de Toxoplasma gondii a los seres humanos, la mayor parte de las veces en presencia de gatos dentro de la vivienda y solamente en comunidades con una alta seroprevalencia de Toxoplasma en niños.

Conclusiones. Los perros pueden ser vectores mecánicos debido a su hábito de revolcarse en sustancias fétidas y de comer heces. En zonas donde la prevalencia de Toxoplasma en niños es alta y donde hay muchos perros y gatos, a las personas inmunodeprimidas y las mujeres embarazadas se les debe advertir del peligro de infectarse con Toxoplasma gondii por contacto con perros o con tierra contaminada por gatos. Se debe alentar a las personas a lavarse las manos después de tocar tierra, perros o gatos $\mathrm{y}$ antes de comer. 